\title{
Property and power: lessons from Piketty and new insights from the HFCS
}

\author{
Miriam Rehm \\ Federal Chamber of Labour Vienna and University of Vienna, Austria \\ Matthias Schnetzer \\ Federal Chamber of Labour Vienna and Vienna University of Economics, Austria
}

This paper argues that the cumulative causation processes between wealth and power risk leading to an escalation of wealth inequality. Piketty's historical description of this development from administrative data for individual countries is corroborated with new survey data for the eurozone, the Household Finance and Consumption Survey (HFCS). Wealth is extremely unequally distributed in the eurozone - much more so than income. Furthermore, we provide a multi-faceted picture of wealth distribution in Europe using the socio-economic characteristics available in the HFCS, and we show that inheritances are the single most important factor for wealth inequality. The structural power to shape economic and political institutions is thus ever more concentrated. Finally, we discuss three channels through which the unequal distribution of private assets may affect power relations and economic activity.

Keywords: wealth inequality, power, Piketty, Household Finance and Consumption Survey

JEL codes: $D 31, E 12, P 16$

\section{INTRODUCTION}

Thomas Piketty's work has placed the debate on distribution center-stage both in mainstream neoclassical economics and in the public. Previously, the focus on distribution in the economics profession was largely a unique selling point of some heterodox schools of thinking, most notably (post-)Keynesianism and Marxism. Piketty has blazed a trail for research on distribution by showing that key premises of neoclassical economic theory regarding distribution, such as the lifecycle income hypothesis or marginal productivitybased remuneration, do not hold up to empirical scrutiny. ${ }^{1}$

Piketty has also revived economic research by refocusing distribution analysis from income to wealth. Important progress in stock-flow consistent modelling within the post-Keynesian school notwithstanding, a focus on flows rather than stocks remains prevalent both in mainstream and in heterodox theoretical approaches. It is likely that the lack of reliable empirical data has played a key role in directing research towards income, and away from wealth.

A new data set published by the European Central Bank now provides a basis for the analysis of wealth in 17 European countries for the first time. This has widened the scope for research on wealth in Europe significantly, and consequently set off a first wave of scientific publications on the topic. In particular, the detailed socio-economic information

1. Piketty's theoretical framework remains firmly rooted in neoclassical economics, and is thus open to criticism from heterodox economics (see for example Taylor 2014). 
available makes it possible to paint a richer picture of the wealth distribution than Piketty's data allow him to do. While time series, of course, are not available for Europe, investigating differences will be possible with the release of the second wave in 2016. The Household Finance and Consumption Survey (HFCS) thus allows for an optimistic perspective for future inequality research in Europe.

From a progressive point of view, it is imperative that research on inequality is not confined to income differentials based on functional or personal income distribution. The question of power, largely neglected in neoclassical mainstream economics, cannot be broached satisfactorily in economics without an understanding of the distribution of the command over resources; that is, in a first and simplifying approximation, wealth. The ownership of wealth affects power relations and economic activity by conferring disproportionate influence on the democratic process to a very small group of actors. The political sphere, in turn, has an impact on the design of the market framework within which economic actions occur, leading to a process of cumulative causation. Piketty shares this point of view; his scientific analysis is borne by his concern for democracy.

Finally, a caveat is in order: this paper is limited to inequality within individual countries and within the group of European countries as a whole. It is beyond its purview to discuss wealth inequality and power relations between countries within Europe or, especially, worldwide.

The structure of the paper is as follows. In Section 2, we discuss the differences between Piketty's data analysis and the HFCS 2010. We then present the first empirical results available for the distribution of wealth in Europe (Section 3), including differences in asset holding between wealth groups, socio-economic characteristics and the gender wealth gap (Section 4), and inheritances (Section 5). Section 6 discusses the implications of this wealth distribution for democratic processes. It briefly highlights the limitations of mainstream economic theory before turning to a discussion of the connection between wealth inequality and democratic power, the concentration of corporate power, and the question of private versus public wealth.

\section{CAPITAL OR WEALTH? PIKETTY AND THE HFCS DATA}

The natural starting point for a comparison of Piketty's work and the HFCS are the bases of their respective data. Piketty's long-term analysis of wealth relies on a plethora of data sources, owing to the breadth of his investigation. In the first part of the book, he focuses mostly on aggregate data from the System of National Accounts (SNA) to trace the development of the ratio between the capital stock and national income net of depreciation (Piketty 2014: 17). For the calculation of differential returns on financial investments resulting from the size of the endowment, Piketty draws on information from trusts of large universities in the United States (ibid.: 447f). Regarding the distribution of wealth, he makes use of wealth tax data, inheritance registers, and probates (ibid.: 18f). Due to the local specificity of these data sources, it is only possible for Piketty to draw conclusions regarding some countries, including France, Great Britain, and the United States. For these countries, Piketty calculates the shares of the top 10 and top 1 per cent in total wealth over 2 centuries.

The HFCS data complement Piketty's analysis by providing a glimpse of the wealth distribution in 17 euro area countries. ${ }^{2}$ The HFCS survey was modeled on the US

2. The countries included are Austria, Belgium, Cyprus, Finland, Germany, Greece, France, Italy, Luxembourg, Malta, the Netherlands, Portugal, Slovakia, Slovenia, and Spain. For simplicity, these are referred to in this article as 'the eurozone' despite missing Estonia and Ireland. 
Survey of Consumer Finances (SCF). As wealth - especially at the upper tail of the distribution - is notoriously difficult to capture adequately in surveys, the ECB went to great lengths to ensure good data quality. This included largely harmonizing the questionnaire for all countries, conducting personal interviews (rather than telephone or online interviews), collecting large amounts of metadata, carefully training interviewers and monitoring computer-assisted interviews in real time, and documenting data processing in detail (ECB 2013a). Missing values are multiply imputed using meta-data to take into consideration the statistical uncertainty associated with imputation procedures. All estimations in this paper thus apply Rubin's rule (Little/Rubin 2002). As a consequence, and despite the indisputable drawbacks of survey data on wealth, the HFCS provides the fullest picture of wealth distribution in the eurozone available to date.

The HFCS explicitly surveys private wealth of households, which contrasts with Piketty's claim to investigate capital; a term used by Piketty interchangeably with wealth. This terminology has rightly irritated (post-)Keynesian economists who understood the capital controversy as proof of the circular definition of capital (Galbraith 2014), as well as Marxist economists who see capital as a means of production since Smith and Ricardo, and as a relation of power since Marx (Duménil/Lévy 2014; Harvey 2014). ${ }^{3}$ A term less prone to misunderstandings is thus probably 'wealth' rather than 'capital.'

The HFCS adopts - like Piketty - a quite narrow, accounting-based definition of wealth. In this sense, wealth consists of economic goods which can generate returns. It must be possible to assign them a monetary value, to use them as collateral, to transfer them, to liquidate them, and, in the case of the HFCS, to attribute them to natural persons. Both Piketty and the HFCS therefore exclude wealth categories such as social wealth (including pay-as-you-go pension systems, unemployment insurance, or public health insurance), environmental wealth (for example, clean air and water, or the lack of noise pollution), and human capital (the innate human capability of producing returns). In contrast to income, these definitions of wealth are not universally accepted. ${ }^{4}$ In particular, the potential future claims on public pension systems are typically found to significantly reduce inequality in wealth.

Piketty's data and the HFCS's differ regarding the sectors whose wealth is accounted for. On the one hand, the HFCS is limited to private households; it thus indirectly includes the corporate sector which is typically owned by households. Wealth that is ultimately owned by legal persons such as certain trusts or associations is, however, excluded. Piketty, on the other hand, uses all sectors of the SNA, at least in parts of his analysis. That is, he includes non-profit institutions serving households and the public sector when looking at the capital stock as a multiple of national income (Piketty 2014: 113f).

The HFCS data are categorized into household balance sheets following an accountingbased wealth definition. Assets include tangible assets, which comprise for instance the main residence, other real estate property, vehicles, and shares in self-employment businesses, as well as financial assets, which contain deposits, shares, bonds, and mutual funds as well as money that is owed by others to the household. Liabilities consist of collateralized and non-collateralized debt.

3. The (sparse) theoretical sequences of Piketty's book are squarely rooted in standard neoclassical theory - yet almost invariably followed by an empirical refutation of the resulting conclusions.

4. While standards for the statistical gathering of income data have been harmonized by the UN at least since the 1970s, the OECD presented an internationally agreed set of guidelines for micro statistics on household wealth for the first time in 2013 (OECD 2013). 


\section{WEALTH CONCENTRATION IN EUROPE}

Owing to the ex-ante harmonization of the HFCS survey, it is possible to compare the available data across countries. However, looking at absolute wealth levels is not particularly meaningful. This is especially the case for median wealth, but also for the mean. The reason lies in the institutional differences of national welfare systems, which affect the necessity of private households to accumulate wealth (Fessler et al. 2012). Countries with a well-functioning social housing policy or pay-as-you-go public pension scheme thus tend to have lower private wealth. A more promising approach is thus the cross-country comparison of distributional aspects, for which the data are very well suited.

Figure 1 lists the countries covered by the HFCS according to their Gini coefficient of net wealth. It shows that Austria, Germany, Cyprus, and France have the highest inequality. At Gini values of up to 0.77 , inequality in wealth is thus much higher than income inequality for all countries as well as for the eurozone as a whole. The wealthiest 10 percent of households in the eurozone own more than 50 percent of total net worth in the HFCS data. In contrast, regarding income flows, the 10 percent of households with the highest income receive roughly 31 percent of total income (ECB 2013b: 96).

Sierminska/Medgyesi (2013) calculate the contribution of the individual asset classes to this total wealth inequality in the countries of the HFCS. The picture that emerges is far from homogenous. While real estate property is the main contributor to wealth inequality in countries like Luxembourg, Greece, and Slovakia, inequality is mostly due to financial assets in Belgium. The unequal distribution of business ownership drives wealth inequality in Germany, Austria, France, and Portugal. This finding on the one hand might not be surprising given the fungibility of capital. On the other hand, it underscores the importance of investigating country-specific aspects in research of wealth inequality - a task which is left to future research here.

The high concentration of wealth found in the HFCS is nonetheless likely to be an underestimation of the actual wealth inequality. Both the willingness to participate in voluntary wealth surveys such as the HFCS at all (response rate), and to answer individual questions on wealth levels (item non-response) declines at the two tails of the wealth

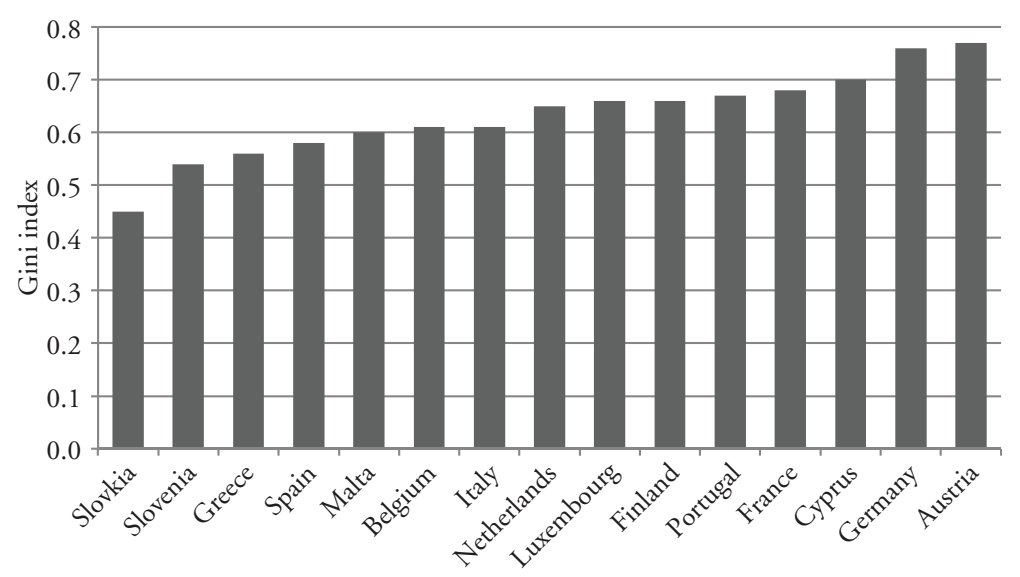

Source: Sierminska/Medgyesi (2013), HFCS (ECB 2010).

Figure 1 Gini index of wealth by country 
distribution. However, as the amount of wealth owned collectively at the lower end of the wealth distribution is negligibly small, the main cause of the distortion lies in the very high wealth levels at the top end of the distribution. ${ }^{5}$

This discrepancy between survey information and actual wealth is made palpable by a comparison between the HFCS data and the Forbes list of the richest people in each country (Vermeulen 2014). ${ }^{6}$ In Germany, the household with the highest wealth in the HFCS survey owns $€ 76$ million, while the household with the lowest wealth out of the 52 Germans covered by the Forbes list has $€ 818$ million. In Austria, the gap is even more dramatic. It spans from $€ 22$ million $^{7}$ (HFCS) to $€ 1560$ million (Forbes).

For this reason, Piketty prefers administrative data on wealth, usually gathered through estate or wealth taxation. These capture the entire distribution of wealth much better, despite problems relating to tax avoidance and evasion, as well as exceptions in the legal definition of the tax base, which often differs from an economic or accountingbased definition of wealth.

Piketty's administrative sources also suggest the underreporting of large fortunes in the HFCS. According to Piketty's data, the top 1 percent in France owns roughly 24 percent of total wealth (Piketty 2014: 340), whereas the HFCS data yield 18 percent for that value. It is thus very likely that the inequality registered in the HFCS underestimates the actual level of wealth inequality. This should be borne in mind in the interpretation of results found from survey information on wealth, and the HFCS data in particular.

This distortion can be corrected for by exploiting the statistical regularity that top wealth levels are distributed according to a Pareto distribution. Vermeulen (2014) exploits this to estimate ranges for the inequality of wealth in selected eurozone countries. Whereas some countries' raw data lie within the band presented by Vermeulen, others - such as Germany, Italy, Belgium, and Austria - seem to underestimate actual inequality to varying degrees. In Germany, for instance, the share of the top 1 percent owns 24 percent of total net household wealth according to the HFCS data. Correcting for underreporting, this share is between 26 and 33 percent. However, even these estimates may not fully capture the extent to which wealth inequality is understated by the HFCS data: even at the upper limit of the range given by Vermeulen's estimates, the share of France's top 1 percent does not reach the 24 percent reported in Piketty's administrative data.

Survey data such as the HFCS's thus clearly underestimate actual wealth inequality and total wealth levels due to underreporting of the top tail of the distribution. This can be partially corrected for, which exacerbates the high inequality observed in wealth as compared to income.

On the whole, the findings from the first wave of the HFCS on wealth inequality clearly support Piketty's main conclusion for Germany, France, and the UK: wealth is extremely strongly concentrated in European high-income countries. The HFCS data allow this finding to be extended to 15 further countries of the eurozone.

5. Some countries that participated in the HFCS attempted to correct for this underestimation through oversampling; however, this was not possible in all cases. The results suggest that countries that oversample achieve a partial correction of non-response bias and the low probability of very wealthy households to be drawn into the sample.

6. It should be noted here that the quality of rich lists does not conform to the most basic academic data standards. Nevertheless, it is the only information available at this point.

7. This number quoted by Vermeulen (2014) refers to a single imputation; taking the multiply imputed nature of the data into account, the value for the wealthiest household would be around $€ 14$ million. 


\section{SOCIO-ECONOMIC CHARACTERISTICS OF HOUSEHOLDS IN THE WEALTH DISTRIBUTION}

The drawbacks of survey data, most notably their underestimation of wealth inequality, are counterbalanced by their advantage of providing an abundance of additional socioeconomic characteristics. These allow the drawing of a more multi-faceted picture of the households owning different levels of wealth than is possible using administrative data. This section offers a first glimpse by showing the participation of the different wealth groups in various asset classes in the eurozone. This is followed by coloring in some details regarding the effects of education and employment status, and a quick brushstroke across the composition of millionaire households. For the latter aspects, results are only available for Austria at this stage.

A first rough sketch of the households making up different wealth groups can be drawn from an overview of their participation in various asset classes. The groups in Table 1 follow Piketty's categorization into the bottom 50 percent, the 'affluent' of the next 45 percent, and the 'rich,' the top 5 percent (Piketty 2014: 246f).

In Europe, the bottom 50 percent owns mainly motor vehicles in real assets, while ownership of the main residence gains importance for the 'affluent.' Other real estate property and shares in self-employment businesses, however, are pivotal only in the top 5 percent group of the 'rich.'

Regarding financial assets, virtually all groups own deposits in sight and savings accounts. Publicly traded shares and mutual funds play a more important role for the 'affluent,' and bonds and other financial assets are more widespread among the 'rich.'

Collateralized debt, on the other hand, is most prevalent among the affluent if secured by the main residence, and among the rich if secured by other properties. Non-collateralized

Table 1 Participation in asset classes by wealth group in the eurozone $e^{\mathrm{a}}$

\begin{tabular}{|c|c|c|c|}
\hline & $<50$ & $51-95$ & $>95$ \\
\hline Vehicles & 61.7 & 84.7 & 91.3 \\
\hline Main residence & 28.0 & 92.1 & 94.1 \\
\hline Other valuables ${ }^{\mathrm{b}}$ & 36.9 & 50.7 & 62.4 \\
\hline Properties (other than main residence) & 8.0 & 35.4 & 78.4 \\
\hline Self-employment business & 6.5 & 14.3 & 49.7 \\
\hline Sight accounts & 92.4 & 96.7 & 99.1 \\
\hline Savings accounts & 56.6 & 63.4 & 67.2 \\
\hline Money owed to the household & 8.5 & 6.4 & 10.2 \\
\hline Bonds & 1.5 & 7.9 & 19.6 \\
\hline Publicly traded shares & 3.9 & 14.1 & 35.0 \\
\hline Mutual funds & 6.3 & 15.5 & 31.9 \\
\hline Other financial assets ${ }^{c}$ & 1.6 & 2.4 & 7.6 \\
\hline Mortgage (main residence) & 13.1 & 26.1 & 20.0 \\
\hline Mortgage (other properties) & 2.2 & 7.5 & 18.9 \\
\hline Other loans & 13.5 & 6.3 & 4.7 \\
\hline Outstanding balance on credit cards & 3.1 & 3.4 & 3.0 \\
\hline Non-collateralized loans & 26.1 & 18.8 & 16.4 \\
\hline
\end{tabular}

Notes: a. Excluding Estonia and Ireland.

b. Other valuables comprise jewelry or paintings.

c. Other financial assets are, for instance, options, futures, precious metals, index certificates, etc. Source: HFCS (ECB 2010), own calculations. 
liabilities, on the other hand, are most common among the bottom 50 percent; their prevalence tends to decrease among higher wealth groups. The form that debt takes is thus linked to the ownership of assets.

While Piketty emphasizes the importance of, for instance, education in the analysis of distributions, his data permit a more detailed investigation only in the chapter on income (Piketty 2014: 304f). The HFCS provides rich information on socio-economic parameters; however, it documents wealth at the household level and socio-economic characteristics at the person level. Here, the so-called financially knowledgeable person, who has the best insight into the financial situation of the household and serves as a respondent in the HFCS interview, is selected as a reference person (Humer et al. 2014).

With regard to education, net wealth increases with each of the four levels of education captured in the Austrian HFCS data. It rises from an average of about $€ 60000$ if the highest level achieved is primary education, to $€ 380000$ at tertiary level (a university degree). Another socio-economic aspect clearly linked to wealth is employment status; the self-employed own about 5 times as much wealth as employees. While employee households have a net wealth of about $€ 180000$ on average, self-employed households have $€ 930000$. The difference is mostly due to the ownership of self-employment businesses, but also real-estate property other than the main residence.

This is also reflected in the socio-economic composition of the millionaire households in Austria. The self-employed are significantly overrepresented among the households with a net wealth over $€ 1$ million. Their share is about 5 times higher than their share in the total population (Humer et al. 2014).

The results presented in this section so far illustrate that the HFCS data can be used to put a face on the wealth concentration described by Piketty. It is of course not possible to deduct conclusions regarding other countries of the eurozone from the findings for Austria; in particular cross-country comparisons are left to future research.

The person-level data contained in the HFCS allow an investigation of the gender wealth gap in the eurozone, in analogy to the gender wage gap. However, this is again hampered by the fact that wealth is available only on the household level. Schneebaum et al. (2014) thus conducted the analysis for male and female (single) households in the eurozone. These households comprise both one-person households and households whose reference person is living without a partner but with children or grandchildren in the household.

The data show a substantial gender wealth gap, which is attributed mostly to a 'wealth glass ceiling' in the descriptive analysis. Male households have a higher net wealth than female households in the top 30 percent, but especially in the top 10 percent (see Figure 2).

The multivariate analysis encompasses a number of possible determinants of differences in net wealth. These include personal information such as age, education, relationship status, age of children, and information on inheritances, as well as labor-market related data including income, employment status, the level of work autonomy, and work history. These labor-market related characteristics, especially income, self-employment, and the lifetime spent in employment, are strongly correlated and in fact largely explain the wealth difference between men and women.

That is, in the eurozone countries of the HFCS, there is a gender wealth gap after quantifiable explanatory effects have been taken into account when standard econometric methods are applied. Labor-market related factors, however, are a very large explanatory factor for the wealth difference between male and female households.

On the whole, the HFCS data thus paint a more colorful picture of the wealth distribution. Broadly speaking, the bottom half of the wealth distribution has mainly cars, deposit accounts, and is often indebted, whereas the affluent typically also own an - often unmortgaged - main residence and bonds. The top 5 percent possess other real-estate property, 


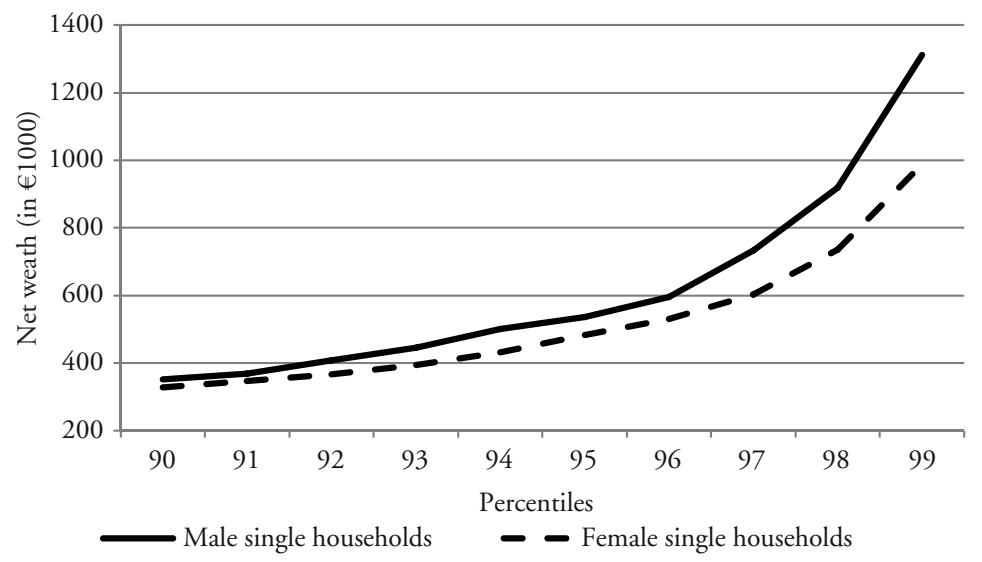

Note: a. Excluding Estonia and Ireland.

Source: Schneebaum et al. (2014), HFCS (ECB 2010).

Figure 2 Top 10 percentiles of net wealth by gender in the eurozone ${ }^{\mathrm{a}}$

more risky financial assets, and business ownership on top of that. Wealth rises with education, and the self-employed own substantially higher wealth. Finally, male households own substantially more wealth than female ones. The next section looks at explanatory factors for the observed inequality in wealth.

\section{INHERITANCES}

One of Piketty's main concerns is the role of inheritances in the rising concentration of wealth. He argues that, at the beginning of the twenty-first century, large fortunes are much more likely to arise from inheritance than from work. This is comparable to the situation in the nineteenth century, when substantial inheritances paved the way to a much higher living standard than high labor income.

Piketty's conclusions regarding inheritances are based on data gathered painstakingly from French administrative archives on estate taxes and probate records established in the wake of the French revolution. Unfortunately, this also means that the results are not easily replicable for other European countries. Here, again, the HFCS can fill in the picture, albeit at the cost of underestimating inequality as survey information on past events such as inheritances is particularly prone to underreporting.

The HFCS can be used to estimate the effect of different explanatory factors on wealth inequality, as a first approach to disentangling the two possible sources of this inequality: savings out of income and transfers (that is, inheritances and bequests). Leitner (2015) applies the Shapley value approach to decomposition for selected HFCS countries. Inheritances make up roughly a third of the predicted inequality of gross wealth, which is by far the largest single factor, on average for all the countries covered (see Figure 3; results for net wealth and real assets are qualitatively similar). In contrast, the contribution from differences in gross household income amounts to about 10 percent. Age and education that is, the influences predicted by the lifecycle and human capital hypotheses - and 


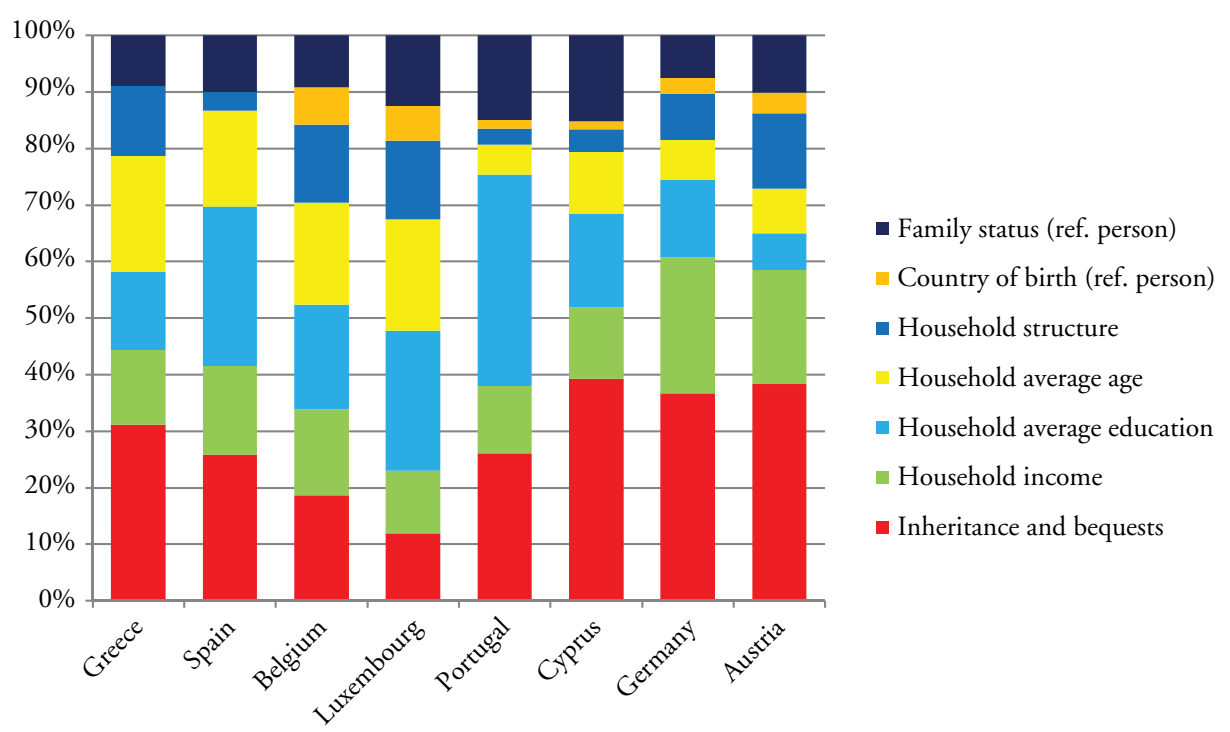

Note: Countries sorted by Gini coefficient for gross wealth. Source: Leitner (2015), HFCS (ECB 2010).

Figure 3 Relative contribution to gross wealth inequality (percentage of predicted Gini coefficient)

other factors such as household composition have a notably smaller impact than inheritances on wealth inequality.

However, there are important differences between countries. In Austria, Germany, and Cyprus, the contribution of inheritances is largest; it lies between 35 and 40 percent. This is combined with the highest Gini coefficients of wealth inequality. However, the differences should not be overstated. Inheritances are the single most important factor contributing to the inequality in gross wealth in all countries studied, with the exception of education in Spain, Portugal, and Luxembourg.

Thus, as Leitner (2015: 21) concludes, '[w] hether or not a person is born into a wealthy and educated family and thus inherits assets determines to a considerable extent whether he or she will make a fortune.' That is, these findings from the HFCS confirm the conclusions that Piketty draws from his outstanding data on inheritances: inheritances are crucial for wealth inequality in Europe. As Piketty stresses, this has important consequences for questions of equality of opportunity and thus the legitimization of the political and economic system. We turn to this question next.

\section{WEALTH INEQUALITY AND POWER RELATIONS}

Wealth inequality has important implications for many facets of the economy and society, and is strongly linked to the question of power. However, this topic is typically neglected in mainstream economics. This section presents the reasons for this, Piketty's take on it, and the approach taken by other social sciences as well as heterodox economics. It concludes by discussing three ways in which wealth inequality may affect economic outcomes. 
Piketty resurrects the Marxist and (post-)Keynesian insight that inequality and capitalism are strongly entangled. His own neoclassical standpoint and anti-Marxist rhetoric notwithstanding, Piketty sees wealth accumulation as a driving force of capitalism.

A key aspect in Piketty's work is the change in dynamics - wealth accumulation becomes a self-fulfilling prophecy - as the size of assets accumulated by a small group, and thus wealth inequality, increase. One channel through which this process takes place is clearly established by Piketty: he demonstrates ingeniously from data on US university funds that larger fortunes entail a higher rate of return, mostly due to higher risk premia and the diminishing costs of asset management (Piketty 2014: 447f).

Another, perhaps more important, channel is less tangible for mainstream economics: that the functions of wealth change as its size increases. This affects economic and societal relationships. The precautionary motive and life-cycle consumption smoothing are very basic functions of wealth (Ando/Modigliani 1963; Carroll/Samwick 1997), both of which are supported to some extent by the HFCS data. Households report precautionary savings objectives, and household wealth in the eurozone peaks at around 55 years of age (Leitner 2015: 20). Larger amounts of wealth entail a broader spectrum of functions, including the preservation of privileges or the enhancement of social status (Van Long/ Shimomura 2004). Very large fortunes may also exert power by influencing political decision processes and even public opinion (Gilens 2012).

While these aspects form an important research topic in political science and sociology, much of contemporary economics has shown less interest in these questions. This is a particular feature of mainstream economic theory. References to power are mostly restricted to monopoly power or bargaining power in goods and labor markets, which are seen as deviations from perfect competition.

By implication, this could lead to the view that the state of perfect competition is a situation free of power influence (Kalmbach 2008). In fact, general equilibrium theory obviates the consideration of power. A renowned contribution to show the irrelevance of power relations is Böhm-Bawerk's paper 'Power or economic law?'8 The Austrian economist questions the possibility of power relations that prevent economic laws from determining prices and the allocation of goods in a long-term perspective. While he does not deal with the question of whether politics in general is able to abrogate economic laws, Böhm-Bawerk was of the opinion that the economic forces of marginal productivity will generally prevail (Berger/Nutzinger 2008). Although the perspective of BöhmBawerk's contribution was not focused on power in general, it is obvious that power relations did not play a major role in mainstream economic theory after the so-called marginal revolution (Dürmeier 2008).

There are multitudinous explanations for this blind spot in mainstream economic theory. One possible reason is the contradiction between neoclassical methodological individualism; that is, the view that economic activity can be traced back to individual decisions of utility-maximizing economic agents, versus the wider perspective of societal classes, which is required for analysing power. This broader perspective, taken by classical economics, invariably entailed the consideration of political and economic conflicts and questions of power relations (Rothschild 2002). The transition from classical to neoclassical economics altered the perspective on economic agents from members of classes to the aforementioned individuals, whose individual actions merely need to be aggregated. The micro-foundations of macroeconomics deflate the relevance of unbalanced power relations or unequal power blocs in a society. As methodological individualism arguably forms part

8. The German title 'Macht oder ökonomisches gesetz?' is translated as 'Control or economic law?' in other publications. The original text was published as Böhm-Bawerk (1914). 
of the hard core of neoclassical economics in a Lakatosian sense (Lakatos 1970), it cannot be abandoned without reformulating the neoclassical framework as a whole.

Another explanation of the absence of power in mainstream economic theory relates to the self-perception of neoclassical economics as an exact science with a physics-inspired methodology (Mirowski 1989; Rothschild 2002). This orientation towards a scientific nature is a unique characteristic that historically impelled the ascension of economics compared to other social sciences. The different epistemological cultures of the various social science disciplines is also the origin of the pretentious views of 'economic imperialism' (Lazear 2000) or the 'superiority of economists' (Fourcade et al. 2015). However, the empirical realist ontology of mainstream economics (Palermo 2007) limits the consideration of real-word economic issues such as power relations. That is, from this view the omission of power in economic theory is linked to the fear of loss of precision and the looming contamination of the pure science through less exact topics that are hard to quantify (Rothschild 2002).

Piketty shares the critique of mainstream economics' lack of focus on power (Piketty 2014: 32). In his view, the discipline of economics has to get over its passion for 'purely theoretical and often highly ideological speculation, at the expense of historical research and collaboration with the other social sciences' (ibid.: 32). However, his work to date does not remedy the shortcoming. In Capital in the Twenty-First Century, Piketty repeatedly alludes to power relations, yet does not explicitly address the nexus between wealth inequality and power. This has not changed in more recent publications. In a follow-up paper (Piketty 2015: 69), Piketty states that the direction of inequality depends on 'the institutions and policies that societies choose to adopt,' but does not document, specify, or even mention the underlying power relations that shape institutions.

Power is a notoriously nebulous concept that is hard to pin down, which could provide some rationale for its lack of consideration in mainstream economics. However, the other social sciences have responded to this challenge by providing a broad variety of power concepts. While the debate is still far from reaching a conclusive or even consensual definition, even basic and unspecific definitions of power in social interactions go beyond the weak implementation in equilibrium theory. For instance, Max Weber (1978: 53) defines power as 'the probability that one actor within a social relationship will be in a position to carry out his own will despite resistance, regardless of the basis on which this probability rests.' A similar conceptualization of power is given by Lukes (2005: 30), where ' $A$ exercises power over $B$ when $A$ affects $B$ in a manner contrary to $B$ 's interest.'

In heterodox economics, these political and sociological approaches have been taken up and extended. The political and sociological definitions cited so far concentrate on intentional behavior in the relations between more and less powerful individuals (relational power). However, in the application to wealth and political power, structural power is important. Dutt (2015) thus argues that the definition of power can be broadened in the optimization approach by considering purposive action to change the 'rules of the game.' The concept of structural power entails the possibility of shaping the framework in which political institutions, economic subjects, scientists, or the media operate. Structural power also comprises setting the public agenda and influencing the norms of discussion - that is, which topics are 'open' to debate and which are off-limits. The aim of structural power is to maintain the prevailing power relations.

(Post-)Keynesian and Marxian economics for the most part retain classical concepts of power resulting from antagonistic class interests. For instance, Kalecki (1943) argues in his famous article on the political aspects of full employment that capitalists oppose full employment due to the social and political changes resulting from the changing power relations to the benefit of the working class. The large body of recent work on functional 
income distributions and the importance of labor market institutions - that is, unions arises from this understanding of power conflicts lying at the heart of economic outcomes.

Marxists explicitly relate power to class domination and the exploitation of labor power in capitalism (Jessop 2012). The basis of the exercise of power is thus the ownership of the means of production, and power is exercised in order to secure the continuity of the social relations between the classes. This 'hegemony' includes defining the prevailing common sense, in Gramscian terminology (Gramsci 1971). Consequently, the Marxist answer to Weber's definition of power is given by Isaac (1987: 96): '[ $r$ ather than A getting B to do something $B$ would not otherwise do, social relations of power typically involve both A and B doing what they ordinarily do.'

In the rest of this section, we discuss three aspects of how the unequal distribution of private assets may affect power relations and economic activity. As an exhaustive discussion of inequality and power is beyond the scope of this paper, we confine ourselves to, first, wealth inequality and the participation in political decision-making processes; second, the concentration of the means of production and corporate power; and, third, the discrepancy between private wealth and public debt as a source of power. In the terminology of Robert Dahl's (1957) seminal paper, we thus focus on the base of power, that is, the underlying resources that $A$ can use to influence $B$ 's behavior (Harsanyi 1962 [1971]).

Regarding the first aspect, the connection between wealth inequality and political power, there is a distinct dearth of empirical work. This is likely to be due to the lack of wealth data on the one hand, and to the difficulty in quantifying power on the other hand. An important exception is Page et al. (2013), who gathered data on wealthy Americans in order to study the differences between their political preferences and those of the general public. They find a remarkable consistency between the preferences of the wealthy and the contours of actual policy in certain areas.

Empirical work on income and power defined as political participation is comparatively plentiful. Gilens/Page (2014) show that income elites and organized groups representing business interests have substantial impact on policy-making in the US, while 'mass-based interest groups and average citizens have little or no independent influence' (ibid.: 565). Bonica et al. (2013) analyse the relation between US voter turnout and household income and reveal a distinct positive correlation. Duca/Saving (2014) document the existence of long-run, bi-directional feedback effects between income inequality and political polarization.

Given the existing empirical evidence, the skewness in the wealth distribution thus arguably affects the possibilities of political participation: affluence appears to determine influence. Wealth is a resource that can be used to wield power, for instance through donations to political parties or payments to lobbyists. Bonica et al. (2013) analyse high-income and small donors of political action committees in the US and show that their ideological preferences differ significantly. These authors accordingly emphasize the feedback effects from politics on inequality through channels like the gradual reduction of top marginal tax rates in many countries. The association between wealth and power is thus not unidirectional, as political influence may be used to create favorable institutional conditions for wealth accumulation.

Regarding the second aspect, the concentration of certain wealth components like business wealth also implies the concentration of corporate power. While concentration and centralization are systemic characteristics of capitalism, corporate power can have a decisive impact on how society functions and is highly relevant for questions of political economy. Harvey (2014) thus does not limit the consequences of corporate capital concentration and monopolistic tendencies to market pricing effects. He argues that the historical process of commodification is the result of the rent-seeking motive and monopolistic 
preferences of capital owners (see also Crouch 2004). Commodification is an expression of changing power relations in a society, as corporations enforce the private (and in the best case monopolistic) production of hitherto public goods.

There are additional developments that change the power relations between corporations and society as a whole. Zucman (2014) shows how multinational corporations maximize their profits by avoiding public taxes through profit shifting and transfer pricing. Big corporations thus do not only use their power to enforce business-friendly institutional settings but also undermine the funding of the welfare state. This is connected to the third aspect discussed here, the discrepancy between private and public wealth.

While public wealth still played an important role in the post-World War II era, privatizations and deregulation have been eroding it for decades. The mirror image of this decline is the ascension of private wealth since the 1970s (Piketty 2014: 128). This development has been accelerated by the financial and economic crisis since 2007. On the one hand, public means were used to restore private wealth through bail-outs of corporations mainly in the financial sector in some European countries. On the other hand, budgets came under further pressure from automatic stabilizers reacting to the recession. The opportunity for downsizing the private financial sector and nationalizing parts of the banking sector was not seized. On the contrary, the fiscal consequences of the financial and economic crisis, and the related the discrepancy between private and public wealth, are felt at all levels of government. As fiscal policy in recessionary environments is severely and unevenly restricted at the European level, public services are increasingly underfunded. This alters the balance of power in favor of private corporations and wealthy individuals in the context of private-public partnerships and donation-funded public services (see for example McCoy et al. 2009). The preferences of democratically legitimated institutions thus, at the very least, needs to be aligned with those of the wealthy elite.

\section{CONCLUSION}

This paper has argued that wealth inequality is a key topic for future research in heterodox economics, because it allows the addressing of the question of power. In our view, the cumulative causation processes between the command over resources and the ability to structurally shape the economic and social framework is of pivotal importance for a progressive understanding of economics.

Two recent developments give a new impetus to this area of research: Piketty's success has sensitized both mainstream economics and the public to issues of distribution, and new data published by the European Central Bank, the Household Finance and Consumption Survey (HFCS), makes it possible to paint a richer picture of wealth distribution in the eurozone.

First results from research using the HFCS data not only confirm Piketty's results, but enrich the analysis through socio-economic characteristics. These findings are, first, that wealth is extremely unequally distributed - much moreso than income. More than half of the countries covered by the HFCS have Gini coefficients higher than 0.6, despite the fact that wealth inequality is underestimated substantially in the HFCS.

Second, whether this wealth is generated through labor income or through intergenerational transfers is crucial for questions of equality of opportunity and thus the legitimization of the political and economic system. Piketty's answer from French archival data is straightforward: large fortunes are today much more likely to arise from inheritances. The HFCS data lead to a similar conclusion: inheritances are the single largest explanatory factor for wealth inequality. 
The cumulative causation processes inherent in wealth accumulation run the risk of leading to an escalation of wealth inequality. On the one hand, as documented convincingly by Piketty, large fortunes reap higher returns. On the other hand, very large fortunes may exert power by influencing the institutions governing economic and political decision-making.

Power is a blind spot in mainstream economic theory. This might be due to methodological individualism running counter to the analysis of social classes and unbalanced power relations, or to physics envy and the fear of loss of precision and quantification.

We argue that (Post-)Keynesian and Marxist economics, by contrast, are better capable of grasping the concept of power and applying it to distributional analysis as they retain classical concepts of class interests. In particular, notions of structural power and hegemony in a Gramscian sense are useful in understanding power conflicts lying at the heart of economic outcomes.

Finally, the paper discusses three selected aspects of how the unequal distribution of private assets may affect power relations and economic activity. First, based on the ample evidence on income and political participation we surmise that wealth is a resource that can be used to wield power, for instance through party donations or lobbying. Second, the concentration of business wealth leads to a decisive impact of corporate power on the functioning of societies. Third, the decline in public wealth compared to private wealth has been accelerated during the financial and economic crisis that has taken place since 2007, as the economic opportunity for downsizing the private financial sector and nationalizing part of the banking sector was not seized. The crisis events therefore entailed a further shift in the balance of power towards the owners of private wealth.

The question of power is thus inextricably interlinked with wealth inequality, and their interplay offers many interesting open questions for heterodox economics, both in theoretical and in empirical work. For instance, theoretical questions around the macroeconomic effects of wealth inequality beyond debt leverage and consumption out of wealth remain under-addressed, as well as issues regarding the accumulation of wealth at different positions in the wealth and income distribution. Empirically, cross-country comparisons of welfare state regimes or the dynamic analysis of the interplay between socio-economic characteristics and inequality come to mind. Given the manifold open questions, the new data, and the renewed interest in questions of distribution by the public and by parts of mainstream economics, we believe that there is an optimistic perspective for future inequality research in Europe.

\section{REFERENCES}

Ando, A., Modigliani, F. (1963): The 'life cycle' hypothesis of saving: aggregate implications and tests, in: The American Economic Review, 53(1), 55-84.

Berger, J., Nutzinger, H.G. (2008): Zum Verhältnis von 'Macht' und 'ökonomischem Gesetz,' Ökonomie und Gesellschaft, Jahrbuch 21, Marburg: Metropolis Verlag.

Böhm-Bawerk, E. (1914): Macht oder ökonomisches Gesetz?, in: Zeitschrift für Volkswirtschaft, Sozialpolitik und Verwaltung, 23, S.205-271.

Bonica, A., McCarty, N., Poole, K.T., Rosenthal, H. (2013): Why hasn't democracy slowed rising inequality?, in: Journal of Economic Perspectives, 27(3), 103-124.

Carroll, C.D., Samwick, A.A. (1997): The nature of precautionary wealth, in: Journal of Monetary Economics, 40(1), 41-71.

Crouch, C. (2004): Post-Democracy, Cambridge, UK: John Wiley.

Dahl, R.A. (1957): The concept of power, in: Behavioral Science, 2(3), 201-215. 
Duca, J.V., Saving, J.L. (2014): Income inequality and political polarization: time series evidence over nine decades, Federal Reserve Bank of Dallas Research Department, Working Paper 1408.

Duménil, G., Lévy, D. (2014): Thomas Piketty's Economics: Modeling Wealth and Wealth Inequality, Unpublished manuscript, URL: http://www.jourdan.ens.fr/levy/dle2014h.pdf.

Dürmeier, T. (2008): Die asymmetrische Geschichte der Kategorie Macht in der Ökonomik, Ökonomie und Gesellschaft, Jahrbuch 21, Marburg: Metropolis Verlag.

Dutt, A.K. (2015): Uncertainty, power, institutions, and crisis: implications for economic analysis and the future of capitalism, in: Review of Keynesian Economics, 3(1), 9-28.

European Central Bank (ECB) (2010): Household Finance and Consumption Survey (HFCS).

European Central Bank (ECB) (2013a): The Eurosystem household finance and consumption survey, Methodological report for the first wave, ECB Statistics Paper Series No 1/April 2013.

European Central Bank (ECB) (2013b): The Eurosystem household finance and consumption survey, Results from the first wave, ECB Statistics Paper Series No 2/April 2013.

Fessler, P., Mooslechner, P., Schürz, M. (2012): Household Finance and Consumption Survey des Eurosystems 2010: Erste Ergebnisse für Österreich, in: Geldpolitik und Wirtschaft, Q3, 26-67.

Fourcade, M., Ollion, E., Algan, Y. (2015): The superiority of economists, in: Journal of Economic Perspectives, 29(1), 89-114.

Galbraith, J.K. (2014): Kapital for the twenty-first century?, in: Dissent Magazine, URL: https:// www.dissentmagazine.org/article/kapital-for-the-twenty-first-century.

Gilens, M. (2012): Affluence and Influence: Economic Inequality and Political Power in America, Princeton, NJ: Princeton University Press.

Gilens, M., Page, B.I. (2014): Testing theories of American politics: elites, interest groups, and average citizens, in: Perspectives on Politics, 12(3), 564-581.

Gramsci, A. (1971): Selections from the Prison Notebooks, New York: International Publishers.

Harsanyi, J. (1962 [1971]): The dimension and measurement of social power, in: Rothschild, K. (ed.), Power in Economics, Harmondsworth, UK: Penguin Books, 77-96.

Harvey, D. (2014): Seventeen Contradictions and the End of Capitalism, London: Profile Books.

Humer, S., Moser, M., Schnetzer, M. (2014): Sozioökonomische Charakteristika der Vermögensverteilung in Österreich, Materialien zu Wirtschaft und Gesellschaft 136, AK Wien.

Isaac, J.C. (1987): Power and Marxist Theory: A Realist Approach, Ithaca, NY: Cornell University Press.

Jessop, B. (2012): Marxist approaches to power, in: Amenta, E., Nash, K., Scott, A. (eds), The Wiley-Blackwell Companion to Political Sociology, Oxford: Wiley-Blackwell.

Kalecki, M. (1943): Political aspects of full employment, in: The Political Quarterly, 14(4), 322-330.

Kalmbach, P. (2008): Anmerkungen zum Verhältnis von Macht und ökonomischem Gesetz, Ökonomie und Gesellschaft, Jahrbuch 21, Marburg: Metropolis Verlag.

Lakatos, I. (1970): Criticism and the Growth of Knowledge, Cambridge, UK: Cambridge University Press.

Lazear, E.P. (2000): Economic imperialism, in: The Quarterly Journal of Economics, 115(1), 99-146.

Leitner, S. (2015): Drivers of wealth inequality in Euro area countries, AK Working Paper Series No 137 (Materialien zu Wirtschaft und Gesellschaft), 1-25.

Little, R.J.A., Rubin, D.B. (2002): Statistical Analysis with Missing Data, 2nd edn, New York: John Wiley.

Lukes, S. (2005): Power: A Radical View, New York: Palgrave Macmillan.

McCoy, D., Kembhavi, G., Patel, J., Luintel, A. (2009): The Bill \& Melinda Gates Foundation's grant-making programme for global health, in: The Lancet, 373, 1645-1653.

Mirowksi, P. (1989): More Heat than Light: Economics as Social Physics, Physics as Nature's Economics, Cambridge, UK: Cambridge University Press.

OECD (2013): OECD Guidelines for Micro Statistics on Household Wealth, Paris: OECD Publishing, URL: http://dx.doi.org/10.1787/9789264194878-en.

Page, B.I., Bartels, L.M., Seawright, J. (2013): Democracy and the policy preferences of wealthy Americans, in: Perspectives on Politics, 11(1), 51-73.

Palermo, G. (2007): The ontology of economic power in capitalism: mainstream economics and Marx, in: Cambridge Journal of Economics, 31, 539-561.

Piketty, T. (2014): Capital in the Twenty-First Century, Cambridge, MA: Harvard University Press. 
Piketty, T. (2015): Putting distribution back at the center of economics: reflections on capital in the twenty-first century, in: Journal of Economic Perspectives, 29(1), 67-88.

Rothschild, K.W. (2002): The absence of power in contemporary economic theory, in: Journal of Socio-Economics, 31(5), 433-442.

Schneebaum, A., Rehm, M., Mader, K., Klopf, P., Hollan, K. (2014): The gender and wealth gap in Europe, WU Working Paper 186.

Sierminska, E., Medgyesi, M. (2013): The distribution of wealth between households, European Commission Research Note 11.

Taylor, L. (2014): The triumph of the rentier? Thomas Piketty vs. Luigi Pasinetti and John Maynard Keynes, The Institute Blog, Institute for New Economic Thinking, URL: http://ineteconomics. org/sites/inet.civicactions.net/files/Lance\%20Taylor-Piketty\%20Paper.pdf.

Van Long, N., Shimomura, K. (2004): Relative wealth, status-seeking, and catching-up, in: Journal of Economic Behavior \& Organization, 53(4), 529-542.

Vermeulen, P. (2014): How fat is the top tail of the wealth distribution? European Central Bank Working Paper 1692, July.

Weber, M. (1978): Economy and Society, Berkeley, CA: University of California Press.

Zucman, G. (2014): Taxing across borders: tracking personal wealth and corporate profits, in: Journal of Economic Perspectives, 28(4), 121-148. 